From Shakespeare to Modern Ages

Racism in Bruce Norris's Clybourne Park

A Post Cultural / Post Racial Approach.

Researcher: Lara Hany Edward Farid

The Department of English Language and Literature

Faculty of Arts,

Menuofia University

\title{
The Abstract
}

For nearly four hundred years ,African Americans have suffered from racism and oppression in the United States of America .They were brought by the European as slaves from Africa in 17th and 18th centuries. About 40 million African Americans, 13\% of the total population, live in the USA today.

In 1860 Abraham Lincoln was elected president of the United States. He was strongly against slavery. Many southern states withdrew from the union and formed their own country - the Confederate States of America. It was the beginning of the Civil War, which lasted until 1865.

After the Civil War, many African Americans have made more and more progress in their political and social life .However, about $25 \%$ of African Americans still live in poverty and suffer from racism under the guise of different new terms like cultural and institutional racism. This research investigates how American dramatists tackle the problem of racism through their plays .It will apply the post cultural/ post racial approach through Bruce Norris's Clybourne Park

\section{INTRODUCTION}

\section{Racism in the Twentieth and Twenty-first Century}

A Post Cultural/ Post Racial Approach

Has America entered a post-racial era? Have racial words like "Nigga" and "Nigger" disappeared from the American conversations? Since the election of President Barack Obama, there has been a discussion that racism has begun its last mile. According to W. Ralph Eubanks, in his radio interview with Rebecca Roberts in the Talk of The Nation, the post-racial refers to "the point where race is no longer an issue or an impediment to progress in American society" or "a colorblind society where race is not an issue". After the election T.V 


\section{Dahlia Kashmiry, PhD}

networks, radio stations and newspapers have begun an intense discussion about the new post-racial America. The conservative radio host Lou Dobbs, for example in The Lou Dobbs Show, said in November 2009, "We are now in a 21 st-century post-partisan, postracial society". Two months later Chris Matthews, MSNBC host, in his television program State of the Union, said of President Obama, "He is post-racial by all appearances. You know, I forgot he was black tonight for an hour". Many people in America think that placing a black man in the most powerful position would rid America of racism. Americans saw the presidential candidacy of Barack Obama, and his election in 2008 as the first black president of the United States, as a sign that the nation has, in fact, become post-racial. For black America, the win of Barack Obama meant a government that would consider and improve their poor conditions. While Obama was a promise for a new post-racial America, many critics, playwrights, and prominent figures, whether they are black or white, have noticed that America is still suffering from racism. In her article in The Guardian (2017), Pamela Merritt mentions that many television commentators are applauding the election of a black president as an indicator that America is now "post-racial" but some Americans can't tolerate Obama's election and some have even questioned whether he is a natural-born citizen and thus meets the constitutional requirement to be president. The growth of the so-called "Birther" movement is charged with the issue of race. During Barack Obama's campaign for president in 2008, throughout his presidency, and afterwards, a number of conspiracy theories falsely asserted Obama was ineligible to be President of the United States because he was not a natural-born citizen of the U.S. as required by Article Two of the Constitution. She doubts that such claims would be made if Obama were not black. President Obama's election was a historical shift, but was it really a sign of pivotal change?

According to the 2016 report "Time for Injustice" of Brookings, a non- profit institution based in Washington D.C, published at Brookings.edu, the $21^{\text {st }}$ century has been difficult for the black in America. It states,

Compared to whites, black Americans face the same risk of unemployment today as in the 1960s. Between 2007 


\section{From Shakespeare to Modern Ages}

and 2013, the net wealth of the median black household fell from 10 percent to 8 percent of median white household wealth, largely the result of the differential impact of the Great Recession. In other words, the median white household now has a net wealth 13 times greater than the median black household. In 2000 the median black household had an income that was 66 percent of the median white household income. In 2015 that figure was 59 percent.

Obama himself told NBC reporter, Lester Holt, in The Reality of Hope show, "I think any talk of it being a post-racial America after my election was never realistic .I think, in fact, that talk was not only naive, but I think created some problems down the road because two things happened. Number one, it meant that African-Americans and other minority groups might have felt as if the problems that have built up over centuries, a wealth gap, an education gap, you know, significant poverty, that those things could be addressed overnight...on the other hand, among, I think some, you know, white voters, who sincerely were glad to see that the country had made this breakthrough, there was also made an unrealistic notion that somehow, 'Okay, that means discrimination's over".

According to Beavers \& D'Amico, 2005, in the area of economics, African Americans are twice as likely as Americans to live in poverty and the median household income for African Americans in 2010 is $\$ 34,218$, only $62 \%$ of the median household income for Americans $(\$ 55,530)$. In the area of education, Americans are nearly twice as likely as African Americans to have completed college (25.3\% versus $13.6 \%)$. In the area of health, Americans are twice as likely as African Americans (19.1\% versus 10.8\%) to have health insurance according to the National Urban League, 2010. In the area of housing, the mortgage denial rate for high income African Americans was three times that of high income Americans (10\% to 30\%) according to Kochhar, Gonzalez-Barrera, \& Dockerman, 2009. Finally, in the field of the criminal justice system, African Americans are six times more likely to be incarcerated according to the Bureau of Justice Statistics, 2008. 


\section{Dahlia Kashmiry, PhD}

In his book Uprooting Racism (2011), Paul Kivel states that African Americans are insecure. They face a lot of disadvantages like: "personal insults, harassment, discrimination, economic and cultural exploitation, stereotypes and invisibility, as well as threats, intimidation and violence" (44). The prevailing of race remains a controversial issue in the American society. The presence of racial practices and health and wealth inequalities, segregated neighborhood and schools have stood next to the claim that America has entered a post- racial era in which race is already past.

In fact Racism in America has a history behind it. According to "Slave Trade" section in the National Museum of the American History website, African Americans were brought to the United States as slaves to work in the cotton lands in the South. Now, they are African American citizens. About 40 million African Americans, 13\% of the total population, live in the USA today.

By the late 1870s Reconstruction began after the time of the Civil War between the North and the South. The American government sent soldiers to protect the freedom of African Americans. In the South African Americans lived in poverty and suffered from discrimination. As a result, they

left the South and migrated to the North, especially to Chicago.

New legal system was established by the government in 1877 . African American men were not able to practice their rights in voting. Legislation known as Jim Crow laws separated African Americans from Whites in schools, housing, jobs, and public places. Jim Crow was more than a set of laws; it was a way of life. In theory, it was to create "separate but equal" treatment, but in practice Jim Crow laws condemned black citizens to inferior treatment and facilities. The living conditions of African Americans deteriorated. Christopher Manning explains in his entry "African Americans" for The Encyclopedia of Chicago,

the second Great Migration (between 1940 and 1960) made Chicago's already overcrowded slums even more dilapidated, as more and more people tried to fit into converted slums even more dilapidated, as more and more people tried to fit into converted kitchenette and basement apartments in which heating and plumbing were poor, if functioning at all. Street 


\section{From Shakespeare to Modern Ages}

crime in African American communities remained a low priority for Chicago's police, and violence, prostitution, and various other vices soared in black neighborhoods. ("African Americans")

The African Americans reflected their sufferings in literature. Most of the African American literature mirrors their memories after the Civil War. Sometimes, their parents or grandparents had been slaves. As a result, a very important literary movement began. It is known as the Harlem Renaissance. It included music, theatre, visual arts and critical writings. Many in the Harlem Renaissance were part of the early $20^{\text {th }}$ century who lived in the Negro neighborhoods of the North and Midwest. Black theater is considered a tool of social protest. Thus, the desire to dominate "the politics of representation" as Stuart Hall calls it (qtd.in African American Performance and Theater History p.6), has an important role in the history of African American theater and performance. Langston Hughes writes in his book The Best of Simple (1986), "Here's to Harlem /They say heaven is paradise/If Harlem ain't heaven/Then a mouse ain't mice” (21).

At the end of the Harlem Renaissance, African American theatre emerged. It offered more authentic views of blacks than those presented by white playwrights. This African American drama was led by the eminent African American Civil Rights and writer W.E.B. Du Bois. When Du Bois established the Krigwa Theatre in 1926, the inaugural playbill for the Krigwa players outlined his philosophy of African American drama and The Crisis magazine published his objective of establishing this theater, "The Negro Art Theatre should be a theatre about us, a theatre by us, a theatre for us and a theatre near us." African Americans used Drama as an instrument for social reform. Many writers during this period tried to reflect the real identity of African Americans. Harry Olufunwa reflects this idea in his essay, "African American Drama of the Harlem Renaissance" (2017):

Towards the end of the Harlem Renaissance, African American theatre received a boost through the Federal 


\section{Dahlia Kashmiry, PhD}

Theatre Project. The positive influence of the FTP continued even after its termination by the U. S. Congress in 1939. One of its major benefits was to help in establishing the American Negro Theatre in 1944. The ANT, in turn, helped to promote playwrights, actors and productions, thereby ensuring the growth of African American drama in the post-Second World War era. The huge number of plays during the period is perhaps best symbolized by the achievement of Lorraine Hansberry's $A$ Raisin in the Sun which was first staged in 1959. Hansberry's triumph has been followed with plays by authors such as Amiri Baraka, August Wilson .(73)

In 1951, before Lorraine Hansberry's A Raisin in the Sun, CBS started Amos $n$ 'Andy, the first sitcom to feature a cast primarily of black actors and actresses. The show was canceled just two years later due to NAACP protest against the harmful images of African Americans that were being projected. The male actors were portrayed as lazy and they depend on others and women as stereotypical housewives. The dialect of characters refers to their lack of education. Analyzing African American theater and performance offers an understanding of how race has affected and continues to affect the American society.

Since Drama has played a significant role in the lives of African Americans to fight racism, this research intends to investigate Bruce Norris's Play Clybourne Park. Norris's Clybourne Park examines racism albeit with a modern twist in the twenty first century .In the play one can explore how a white playwright like Bruce Norris claims that racism is still part and parcel of the lives of white people .The play tries to answer the question: Is this what racism looks like in a post-racial era? .

\section{BRUCE NORRIS'S CLYBOURNE PARK}

In Norris's Clybourne Park - being inspired by Lorraine Hansberry's 1959 play A Raisin in the Sun - a battle over race and real estate rages across two generations in a suburban Chicago neighborhood. With a modern twist on issues of race, class, property ownership and community, Clybourne Park revolves around 


\section{From Shakespeare to Modern Ages}

discrimination, gentrification and political correctness. The idea of the play came to Norris when he was a child. He said that the first play he saw at school was Hansberry's A Raisin in the Sun. In an interview with Beatrice Basso (2011), he speaks about the play and says:

I was obsessed with that play [A Raisin in the Sun] when I was a kid ... I first saw the play when I was 12, right around the time that I was starting to hate authority. That play has resonated all through my life because I realized that the only character I could identify with was Karl-I was a whitey in an all-white neighborhood in Houston, Texas. I really loved the play. I was always regretful that I never got to play Karl Lindner, so I thought I'1l just give him some more to do [by writing him into Clybourne Park].That's a way of getting to play that part indirectly.

Bruce Norris is an American actor and playwright. He graduated from Chicago's Northwestern University in 1982 . He began his career as an actor. He performed at many theatres like Victory Gardens Theatre and Goodman Theatre. In 1997 he moved to Brooklyn, New York, where he currently lives. His major film appearances include A Civil Action, The Sixth Sense and All Good Things. His play Clybourne Park premiered at Playwrights Horizons in New York in January 2010 and received its UK premiere at London's Royal Court Theatre in 2011. The play also won Olivier Award for Best New Play and the Pulitzer Prize for Drama.

Reviewing the play in his article in The Column, Jeremy William Osborne said that the Pulitzer Prize committee citation described Clybourne Park as "a powerful work whose memorable characters speak in witty and perceptive ways to America's sometimes toxic struggle with race and class consciousness." Bruce Norris's other plays have received their world premieres at Chicago's Steppenwolf Theatre. These include: The Infidel (2000) Purple Heart (2002) We All Went Down to Amsterdam (2003, Joseph Jefferson Award for Best New Work) The Pain and the Itch (2004, Joseph Jefferson Award for Best New Work) The Unmentionables (2006) A Parallelogram (2010). 
Bruce Norris's Clybourne Park describes the same house in Lorrain Hansberry's Raisin in the Sun in the predominantly white neighborhood where the Younger family, a black family, intends to live. The same house is described in the second Act fifty years later where a white family intends to move to, but this time the neighborhood has become predominantly black. Clybourne Park has received a lot of attention in the media, especially in light of recent racial issues in America. Ben Brantley makes two very interesting claims in his review of Clybourne Park, "Slashing the Tires on the Welcome Wagon." He claims that Bruce Norris "efficiently dashes the cautious hopes" of the family in A Raisin in the Sun, so one would imagine they play to be a "downer. While communication between blacks and whites improves throughout the two acts of the play, dialogue is strained. Conversations are full of political references, and there are a lot of pain behind every sentence said. Dialogue are offensive and without progress. Although there is fifty years between the two Acts, the lack of communication proves to be a essential problem in the house. On the surface, communications seem to be much better, but in reality conversation is very unpleasant as it was fifty years earlier. Clybourne Park is ultimately a play that focuses on racial issues that have not improved yet. Bruce Norris claims that the same fundamental problems will always exist, and communication must improve to make any progress. He believes that a lot of superficial changes have happened like in laws, the public services, and education. However, our nature refuses to change accordingly. Legislations and laws cannot change our feelings towards each other.

The play is set in Clybourne Park neighborhood. It consists of two Acts. The first one is set in 1959 and the neighborhood is mostly white, while the second Act is set in 2009 and the neighborhood changes to be predominantly African American. Norris uses the same house in Hansberry's A Raisin in the Sun -the house which the Youngers decided to move to after leaving their slum - as a start to his play. The play opens with Bev and Russ Stoller, two white characters, packing their things because they want to move out from Clybourne Park. They had a son called Kenneth who committed a suicide because the community accused him of killing innocent people during the Korean War. The couple can't tolerate the community's behavior 


\section{From Shakespeare to Modern Ages}

towards their son and they think that their attitude was the main reason why Kenneth committed suicide. As a result, they decided to leave this neighborhood. Another couple is Francine and Albert who are black. Francine is a servant at the Stoller's. She is always targeted by questions from Karl Linder and Jim. Karl Linder is a recurrent character. He appeared in Hansberry's A Raisin in the Sun as the white character who tries to convince the Youngers not to move to Clybourne Park. Norris uses the same character in his play. Karl appears in the first Act trying to persuade Bev and Russ not to sell their house to a black family. He is married to Betsy who happens to be deaf and pregnant. Jim is a minister who appears in the first Act because he has been asked by Bev to talk to Russ about his nonstop mourning of his son's suicide. The action is reversed in the second Act. A white couple, Steve and Lindsey, wants to buy the same house portrayed from Act one. They want to renovate it and demolish most of the original structure, but Lena and Keven, a black couple who represents the Home Owner's Association, tries to explain the historical importance of this house to them and that whether the new house to be built at 406 Clybourne Street conforms to the specifications of the Community Association. Later in this Act, one knows that Kathy, the lawyer of Steve and Lindsey, is the daughter of Karl and Betsy. Also, Lena's great aunt lived in this house after the Stoller's. Kevin and Lena tell Steve and Lindsey about what happened in this house 50 years ago. Lindsey can't live with the fact that Kenneth hung himself in this house. Tom, a real estate lawyer, is another character who leads the discussion among the characters and represents the interests of Lena and Kevin . Dan is a contractor who discovers a mysterious box in the yard.

Norris's aim to set the first Act in 1959 and the second in 2009 is to portray the society where racism was an explicit issue in 1959 and everybody in Act One speaks about it in a direct way; despite fifty years, racism has still been an issue. The only difference is that racism in 2009 is implicitly expressed and everybody in Act Two is embarrassed when the issue comes up to the surface. In the play, time has stood still. Nothing changes over 50 years except for the physical appearance of the house. In the first Act the house is nice and well- 
kept while in Act 2 it erodes and deteriorated. When Emily Hoffman interviewed the Scenic Designer Ralph Funicello and asked him about the challenges of designing Chicago bungalows, he said:

They're primarily brick Craftsman houses that have a lot of oak. When they were originally built they had a lot of plain, square oak detailing inside, very much the kind of thing that [playwright] Bruce [Norris] describes in the play: the built-in sideboard and the paneling and plate rack in the dining room. The problem is that we have to make the house look fairly deteriorated for the second act, so that really necessitated our not doing oak-finished woodwork. But if you figure that in 1959 this house was already 50 years old, it's quite possible that the woodwork was painted.

The second Act mirrors the first Act. One can also notice that there are family ties among the characters. By doing this, Norris wants to attract the attention that different generations inherit the same racial feelings and attitudes. Ben Brantely writes in New York Times review of the play (2010) about how "the emptiness of most human communication" is evident in all the characters' interactions. Indeed, much of the stage time is taken up with trivia, small talk, and niceties. Although moments of true connection between characters are rare, the play seems to urge its readers to be patient and learn to listen in order to communicate successfully.

Symbolism in the play can't be ignored. Norris uses it to deliver many messages. One can find symbolism in the characters' actions and in objects. Bev and Betsy in the first Act are housewives. Bev is doing the housework while Russ is sitting in his chair all the time. Betsy is a deaf woman who only hears what her husband tells her. Both characters symbolize the role of women in 1959. Fast forward to the twenty first century, Lindsey is seen as a wife who argues with her husband and she doesn't allow anybody to filter information for her. Francine, in the first Act is seen as a maid in Russ's house ,while Lena in the second Act, is seen as a lawyer who defends the rights of African Americans to keep their culture. Here symbolism is used to emphasize the big change that has happened between generations in the two acts. 


\section{From Shakespeare to Modern Ages}

Symbolism is not limited to characters; it is employed by objects too. Bev and Russ are seen in the first Act arguing over who would carry a trunk that is too heavy and its contents are hidden from the audience until the end. The trunk seems to symbolize the burden that Bev and Russ have carried since their son, a Korean War veteran, committed suicide after struggling with having killed innocent citizens. Bev reminds Russ about carrying the trunk, but he replies that it is a "two person job," implying that he cannot carry the burden on his own. Instead of volunteering to help, Bev indirectly asks Lena and her husband Albert, to bring down the trunk. Even though Russ was not eager to carry the trunk by himself, he is angry when he sees other people carrying the load for him. In this way, Bruce Norris uses the trunk to represent Russ' struggle between pain and pride. Because of this pain, Russ doesn't mind selling his house to a black family. It is his way of revenging himself on his neighbors who failed to accept his son. Unlike Karl, the only thing he wants is to leave this neighborhood. In Act One Russ says to Karl:

RUSS: If you honestly think I give a rat's ass about the goddamn - . . . what ya' mean the community where every time I go for a haircut, where they all sit and stare like the goddamn grim reaper walked in the barber shop door? That community? ... Where Bev stops at Gelman's for a quart of milk and they look at her like she's got the goddamn plague? That the community I'm supposed to be looking out for?. . . Well, you go ahead and you tell those folks whatever you want, Karl. And while you're at it why don't you tell _em about everything the community did for my son. I mean, Jesus Christ, Murray Gelman even goes and hires a goddamn retarded kid, but my boy? (1.1)

Many similarities can be found between the characters in Act One and in Act Two. In the First Act, Karl Linder is the racist. He is the one who is concerned about the moving of a black family to Clybourne Park. First, he doesn't bother to know Francine's name, the only black character in the play. He asks, "Uh, Francine, is it?"(Clybourne Park, 1). Karl always showers Francine, the house 


\section{Dahlia Kashmiry, PhD}

keeper, with questions to prove that the black and the white can't live together:

KARL: Francine, may I ask? Do you ski?

FRANCINE: Ski?

KARL: Downhill skiing?

FRANCINE: We don't ski, no.

KARL: And this is my point. The children who attend

St. Stanislaus. Once a year we take the middle schoolers up to Indianhead Mountain, and I can tell you, in the time I've been there, I have not once seen a colored family on those slopes .Now, what accounts for that? Certainly not any deficit in ability, so what I have to conclude is that for some reason, there is just something about the pastime of skiing that doesn't appeal to the Negro community. And feel free to prove me wrong... But you'll have to show me where to find the skiing Negroes. (1.1)

In this conversation, Karl wants to clarify that some sports like skiing are not interesting to African Americans. This reminds us of August Wilson's Radio Golf, where golf is the symbol of a sport played only by the white rich people. Karl continues to ask Francine: "I think that you'd agree, I'm assuming, that in the world, there exist certain differences. Agreed?" (1.1). He explains,

KARL: Different customs, different . . . well, different foods, even. And those diff-here's a funny-my wife, Betsy, now Betsy's family happens to be Scandinavian, and on holidays they eat a thing known as lutefisk. And this dish, which I can tell you ... (he chuckles) . . . is not to my liking at all. It's . . .oh my goodness, let's just say it's gelatinous (1.1).

In this exchange he tries to justify his racism by giving an example of a food that his wife likes while he doesn't find it delicious because she is Scandinavian and he is not. Food and taste are employed by Norris to show that they are manifestations of the competition that's going on with all people all the time. Every ethnic group tries to express themselves through insignificant things like taste or kinds of clothes. For example, the rich people in a city would demonstrate their richness by buying expensive clothes and eating expensive food. In his interview with Basso, Norris states " at any 
From Shakespeare to Modern Ages

given moment, you know that even something as insignificant as taste-"I like this house better than that house, it's prettier" identifies us as part of a group that looks at another group skeptically or critically."

Jim, the minister, continues to offer more cultural differences by speaking about the musical instruments that each team use in churches. He says,

JIM: - You do find differences in modes of worship. If you take First Presbyterian. Now that's a church down in Hamilton Park and I've taken fellowship there and I can tell you, the differences are notable ... Not a value judgment. Apple and oranges. Just as how we have our organ here at Saint Thomas, for accompaniment, whereas at First Presbyterian they prefer a piano and, occasionally ... (chuckles) . . . well, tambourines. (1.1)

Throughout the conversation Karl and Jim always try to interrupt Francine giving her no chance to state her opinion because they want her to say what they want to hear. When they ask her if she would enjoy living in Clybourne Park, Francine says, " It's a very lovely neighbor- " , but is interrupted by Jim asking her to be honest (Clybourne Park,1). In their conversation with Francine, Karl and Jim show that African Americans are inferior and deal with them as second class persons. They don't have the right to live where the Whites live or eat what the Whites eat.

In Act Two, Steve is the racist. He tells offensive jokes about race and class. Everybody in Act two is trying to be politically correct regarding race and class. They speak about these issues implicitly, except for Steve who can engage himself in discussions about race without paying attention of what he is saying. When Lena starts a discussion about the hidden interests behind gentrification and how some of these interests are not economic, she immediately realizes that she has to stop talking about this and she tries to avoid answering Steve's question "which group? "(2.1). Steve, on the other hand, speaks explicitly and says

- Okay Okay. If you really want to - It's ... ...it's race. Isn't it? You're trying to tell me that that ... That 
implicit in what you said - That this entire conversation ...isn't at least partly informed -am I right? By the issue of ... of racism?. (2.1)

There is also a similarity between Bev in the first Act and Lindsey in the second Act. Both of them seem to reject the idea of grouping people according to the color of their skin but in depth they fail sometimes to keep themselves from being racist. Bev, in the First Act for example, tries to give Francine, her maid, and her husband ,Albert, a chafing dish. She thinks that ,as a black couple, they might not have something like that. She says:

Bev: Do you own one of these

yourself?

Francine: No, I sure don't.

Albert and Francine politely refused the chafing dish .

Albert: Well, we got plenty of

dish-

Bev: Not one of these. Francine

told me.

you, but -

Albert: Well, that's very kind of

Bev: She said you didn't have one and somebody should take it and -

Albert: But we don't need it, ma'am. (1.1)

Although Francine is Bev's maid for a long time, she forgets how many children Francine has. Bev says she would be "So honored " to have Albert and Francine and their two children as her neighbors (1.1). Albert has corrected her by saying that they have three children. Bev assumes that she cares for Francine and her family, but her actions prove the opposite. For her, they are only a poor couple who she tries to help by giving money or house ware. At the end of Act one, Bev tries to offer Albert some money for helping her. She says, " Well, here, then. Let me at least give you fifty cents ", but Albert 
From Shakespeare to Modern Ages

refuses to take the money and he says, "No, now you keep your money." (1.1). Then Bev explains that the only solution to this situation is that the black couple should know what the others eat to be able to sit down together. Albert ignores her conversation and leaves with Francine.

In Act two , Lindsey mirrors Bev. She also pretends not to be a racist but sometimes she fails. She always tries to choose her words and to be politically correct. When she explains to Lena why she wants to live in Clybourne Park, she says:

LINDSEY: And I totally admit, I'm the one who was resistant, especially with the schools and everything, but once I stopped seeing the neighborhood the way it used to be, and could see what it is now, and its potential? (2.1)

Here Lindsey is referring to the neighborhood when it was predominantly black and " the way it used to be " as an area full of crime and drugs. Lindsey realizes that she has said something about race. Steve tries to help her by completing her sentence and says:

STEVE: (Helpfully, to Lena) What you said. About the history of - ?

LINDSEY: Historically. The changing, you know, demographic_-?

STEVE: Although originally-(To Lindsey) wasn't it German, predominantly? (2.1)

Lindsey doesn't want to appear a racist. She always tries to be politically correct. This what Bruce Norris wants the audience to think about. He wants to say that in 2009 speech is more important than action. . In an interview with Beatrice Basso, Norris comments on the characters' interactions: " Everyone holds their tongue, because we live in a society where speech is much more dangerous than activitythan action .... No one knows that they should be embarrassed in the first act; everyone knows they should in the second act. We're embarrassed about everything". When Steve, Lindsey and Kathy want to speak about how Clybourne Park was suffering in the sixties and seventies, they try to choose their words carefully: 


\section{Dahlia Kashmiry, PhD}

STEVE: - of the neighborhood and how in the seventies, eighties, how that was followed by a period of - of - of - of - of rapid KATHY: Decline.

LINDSEY: No-Not-No

STEVE: Of growth. Of growing -

KATHY: I don't mean decline -

KATHY: - I mean there was trouble.

LINDSEY: Not trouble, she didn't mean -

KEVIN: There was trouble.

LINDSEY: Economic trouble. (2.1)

Also, Lena tries to be politically correct. Sometimes she uses a coded language instead of speaking explicitly. She talks about the historical significant of that house and the neighborhood to her and how she had memories that connect her to the area but she wants actually to tell the white couple to go away and leave the neighborhood.

Not only can similarities among characters be found but also parallelism in discussions between Act one and two. Act one opens with a discussion between Bev and Russ about names of cities and nationalities. They talk about the origin of the word Neapolitan and then about what people who live in various cities are called. Also, in Act two, the white and black couples engage in a discussion about countries and places they visited like Morocco and Spain. Bruce Norris sends a message that a territory is very important to the human being and that owning a physical place might be the reason for a racial conflict. This is why he manages to open both acts with a discussion about countries and cities.

The theory of symbolic racism by Sears is very clear in Norris's play. In the First Act, Karl tries explicitly to push the black family from the white neighborhood as he is still affected by Jim Crow segregation laws. While in the Second Act, Steve and Bev try implicitly to push the black couples from the black neighborhood under the name of gentrification. In the First Act, there is the old Jim Crow. In the second Act there is the New Jim Crow. Reviewing the play, Alex Brown writes in Seven Days, "Clybourne Park is a clever time capsule, satirizing the polite bigotry of the ' 60 s by contrasting it 
From Shakespeare to Modern Ages

with today's earnest avoidance of the political and psychological force of race and class" (Brown, 2018).

Bruce Norris wants to confront the comfortable audience with things they would rather avoid. His play becomes a pressure to make the audience think about how in the post racial era, there are black families thrown in the face of gentrification. He mentions in his interview with Beatrice Basso that racism is another version of the same thing that leads to wars. It is not only about African Americans and the Whites but it is about the human kind. The surface issue in Act Two is whether the house to be built in Clybourne Park conforms to the specifications of the community or not, but deeply, Norris wants to show how place and human identity are linked. Lena focuses on this by saying :

LENA: Well . . . I have no way of knowing what sort of connection you have to the neighborhood where you grew up? ... And some of our concerns have to do with a particular period in history and the things that people experienced here in this community during that period- . . --both good and bad. And on a personal level? I just have a lot of respect for the people who went through some of those experiences and still managed to carve out a life for themselves and create a community despite a whole lot of obstacles? . . . Some of which still exist. That's just part of my history and my parents' history-and honoring the connection to that history - and no one, myself included, likes having to dictate what you can or can't do with your own home, but there's just a lot of pride, and a lot of memories in these houses, and for some of us, that connection still has value, if that makes any sense? . . . For those of us who have remained. . . And respecting that memory, that has value, too. At least, that's what I believe. And that's what I've been wanting to say. (2.1)

Lena is trying to summarize the negative effects of gentrification on the black people. She explains that it is not only about houses made of bricks and cement, but it is about memories and history and a whole culture stored in such structures. If they are going 
Dahlia Kashmiry, PhD to gentrify those building, they are going to remove all the connections to this history and this culture. Lisa Mckenzie describes gentrification as a violent process, "It's not about cupcakes and cereal cafes, it's about people being literally ripped out of their homes and their communities" (qtd.in Poppy Noor, 2018). She suggests that gentrifiers harness their guilt by campaigning for the local services that become neglected in an area when wealthier residents move in

For some residents gentrification means new buildings and improvements to public places and facilities like libraries, stores, and transportation. It means more job opportunities, investments and less crime rates. For others, it refers to the demolition of familiar buildings and the destruction of their memories and their historical identity. Dan Rubin defines gentrification in his article "What is Gentrification?" as "the process by which the arrival of new amenities and higher-income residents causes a neighborhood's essential character to change, both in terms of population and aesthetics " (Rubin,2011).

In Clybourne Park, Bruce Norris links gentrification to white flight. When he tries to persuade Bev and Russ not to sell their house to an African American family, Karl Linder asserts "First one [white] family will leave. Then another, and another, and each time they do, the values of these properties will decline, and once that process begins, once you break that egg, Bev, all the king's horses, etcetera "(1.1). Karl Linder is right in his prediction because this is what exactly happens in the second Act of the play when Clybourne Park becomes predominantly black. White flight refers to the departure of the white people to avoid racial integration between 1940s to 1960s. This movement led to poverty, unemployment and crime. To solve these problems, some city governments decided to begin the process of renovating such cities to attract the Whites again. What happens in the fictional Clybourne Park in the play, happens in many areas across the United States. Chicago is one such example of these gentrified cities. According to what Larry Bennett writes in encyclopedia.chicagohistory.org, in the late 1950s the city of Chicago started a renovation project in Lincoln Park, which resulted in considerable housing demolition in the southeastern portion of the neighborhood, especially along North Avenue. Since the 1970s gentrification has spread to many other areas in Chicago 
From Shakespeare to Modern Ages

("gentrification"). After gentrification, these areas attracted many businesses and entertainment projects. The lifestyle of this neighborhood became urban. Many investors began to buy properties there. As new buildings and houses appeared, rich buyers moved in. The process began, one white family came in, then another, another and another. Once that egg was broken, all the king's horses, etcetera . The Loyola University Chicago Center for Urban Research and Learning conducted a study in 2006 to investigate the impact of gentrification on African Americans in four communities in Chicago. This study explains that "the physical appearance of new development is seen as being insensitive to the visual character of the existing community. New houses are described as 'cookie-cutter' houses that threaten the distinctiveness of the community" (Nyden, Edlyn, Davis). The current residents of the city perceive this process as destruction to their old houses to give more spaces to the rich new residents. The original residents expressed their feelings and opinions towards gentrification. They explain,

that new residents matter more to the city and have more power ... [and] a feeling that current residents are blamed by new residents for the community's problems. City beautification efforts are sometimes seen not only as 'welcome mats' for gentrifiers, but more importantly, the result of the 'new rich' in gentrified communities having more clout to get the city to make such improvements," rich' in gentrified communities having more clout to get the city to make such improvements," ( qtd in. Dan Rubin "What is Gentrification?").

. In his article "Gentrification: Culture and Capital in the Urban Core" Sharon Zukin writes that gentrification leads to "geographical reshuffling"(abstract). Commenting on the findings of a Manhattan Institute for Policy Research study, Stefano Esposito, in his article "Chicago Tops Nation for Segregation, but Sees 2nd-largest Decline in U.S." explains :

The study describes the 1960s as the 'heyday of racial segregation.' 'During those years, the fight against housing segregation seemed to offer the possibility that once the 


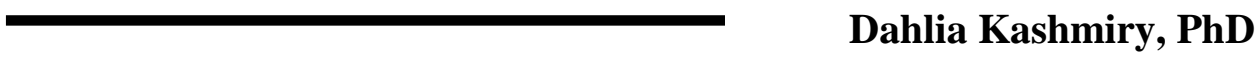

races mixed more readily, all would be well. Forty years later, we know that this dream was a myth,' the report said. 'There is every reason to relish the fact that there is more freedom in housing today than 50 years ago and to applaud those who fought to create that change... At the same time, there has been only limited progress in closing achievement and employment gaps between blacks and whites.'

In Clybourne Park, Norris advocates the idea that America still has racism but without racists. Most of the Whites assert that they are not racists like Bev and Lindsey in the play. They claim that they have a lot of black friends. They don't see their color. Moreover, most Whites blame African Americans for most of the problems they face. They claim that African Americans play with the race card whenever they suffer from any problem. For Blacks, their situation now is worse than in the past. While in the past racism was overt and clear, today it is hidden and justified. These justifications absolve them from any responsibilities towards people of color. While old Jim Crow laws were created on the basis of the biological inferiority of African Americans, New Jim Crow racism perceives the poor social status as a result of contemporary behavior. Shielded by these justifications, the white people can criticize African Americans' morality, values and work ethics. Furthermore, they can even complain about reverse racism. The white racists believe that racism is a thing from the past and this is why when African Americans try to protest about being racially discriminated in housing, job market, schools, restaurants and other public places, their protest is interpreted as laziness and excuses. In their article, in 1997, "Is Subtle Prejudice Really Prejudice?" Roel

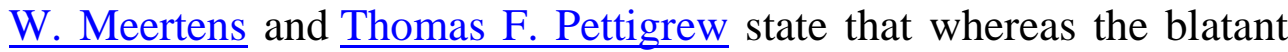
prejudice of old racism was "hot, close, and direct," the new subtle prejudice is "cool, distant, and indirect" (54). New racism and the concomitant color-blind racial order believe that white achievements have nothing to do with race but are related to hard work and merit. As a result, race-conscious policies are considered unnecessary and even a disadvantage to whites through reverse racism.

Nowadays, people in America live in a society that claims to be without racists whilst racism shapes the daily lives of the society. The white citizens declare they are not racists. On the other hand, the 
From Shakespeare to Modern Ages

people's practices and the oppressive policies still exist. Colorblindness is the new technique adopted by the Whites as a way of justifying contemporary racial inequality that is softer and kinder. Colorblindness still has the same goal as the old forms of racism.

In his book Racism Without Racists: Color-Blind Racism and the Persistence of Racial Inequality in the United States, 2010, Bonilla-Silva has made a lot of interviews with many groups of all ages and discussed many subjects about all walks of life. He focuses on the frames with which the Whites continue to use nowadays to be racists. These frames include abstract liberalism, naturalization, cultural racism, and the minimization of race.

Economic and political liberalism allow the Whites to seem more moral. For example, the issue of quotas is not liked by the Whites. They think that it is a privilege that is given to African Americans and they should be provided with equal opportunities. This opinion seems moral on the surface but actually it bears racist attitudes.

Naturalization is used to clarify how groups of the same race are attracted to each other. It is something that is inherent in all human beings. Instead of discussing the societal structures that result in segregation, Bonilla- Silva finds that the Whites tend to explain the issue as if it is "natural" that people have friends and neighbors of the same color and race. Cultural racism is a frame the Whites uses that focuses on the flaws of the black culture. They blame the black culture for supporting laziness and the lack of work ethics. Many Whites suggest African Americans want short cuts to earn money.

Finally, the minimization of race frame suggests that racism is no longer an issue and it disappears. The Whites see themselves as not racists, and African Americans are not qualified.

Bruce Norris writes his play because he wants to confront his audience that racism is still rooted in the American society. In 2017, Natalie Y Moore writes in The Guardian:

Chicago murders may make the headlines, but our problems of violence actually stem from something larger, something many other American cities face: racism, segregation and inequity. Chicago is a microcosm of a larger American story. 


\section{Dahlia Kashmiry, PhD}

Uprisings in Ferguson, Missouri, and Baltimore illustrate the racial tension that's in part defined by deep-seated housing segregation.

In her article, she mentions a news story that was broadcasted on CBS news magazine show 60 Minutes. This news story was about the violence on Chicago. She continues to say that the "The segment, called Crisis in Chicago, did not get to the deep causes of violence and was skewed heavily towards the police. Ousted former police superintendent Garry McCarthy accused the Black Lives Matter movement of creating anti-police sentiment". She continues to explain that "If Chicago isn't Chi-raq", a combination of two words , Chicago and Iraq "or the murder capital of the world, murder capital of the US or even of the Midwest, what are we? We do have more murders than Los Angeles and New York, cities with larger populations. And Chicago does have the dubious distinction of being the urban face of gun violence. On the presidential campaign trail, Donald Trump joined the fray by calling inner cities such as Chicago "hell" for African Americans and Hispanics.

At the end of the play, Bev, the character portrayed in Act I, comes on the stage again. She speaks to her son Kenneth, who committed suicide after killing people in the Korean War. She says, "But you know, I think things are about to change. I really do. It's been a hard couple of years to all of us, I know they have been, but I really believe things are about to change for the better. I firmly believe that" (2). Bev here makes everyone thinks about the situation that has started in 1950s and has not yet ended in 2009. White people moved out of the neighborhood, black people moved in, and now white people want to get in again in the neighborhood, meaning black people will probably get pushed out. The two races never live with each other. Bruce Norris invites people to solve their racial problems without explicitly stating that.

H. Roy. Kaplan in his book The Myth of Post-Racial America: Searching for Equality in the Age of Materialism (2011) says:

Not a day goes by in the United States without a racial incident from the savage beatings and murders of color, to job and housing discrimination and the myriad of petty 


\section{From Shakespeare to Modern Ages}

insults that mock the founding principles of our society- all Americans are faced with consequences of racism".(ix)

Kaplan asserts that racism still matters in the United States even today. He adds that since the election of Barack Obama many people have thought that America has begun the post racial era as a black man inside the White House indicates that the nation matured and fulfilled the original American dream of equality among all people. However, this view is not realistic because color still permeates the American life.

In his speech in 1968, Martin Luther King, Jr. spoke about what he called the two Americas. He says:

There are two Americas. One America is beautiful for situation. In this America, millions of people have the milk of prosperity and the honey of equality flowing before them. This America is the habitat of millions of people who have food and material necessities for their bodies, culture and education for their minds, freedom and human dignity for their spirits. In this America children grow up in the sunlight of opportunity. But there is another America. This other America has a daily ugliness about it that transforms the buoyancy of hope into the fatigue of despair. In this other America, thousands and thousands of people, men in particular walk the streets in search for jobs that do not exist. In this other America, millions of people are forced to live in vermin-filled, distressing housing conditions where they do not have the privilege of having wall-to-wall carpeting, but all too often, they end up with wall-to-wall rats and roaches. Almost forty percent of the Negro families of America live in sub-standard housing conditions (king, thekingcenter.org)

Martin Luther King, Jr. divides America into two Americas. One of them is providing good life and good opportunities. It offers millions of people dignity and freedom. It gives them educational, cultural and material necessities. On the other hand, there is another America with an ugly face that turns only to African Americans. It provides despair and hopelessness. In this America dreams of freedom have been deferred. Martin Luther's point of view in 1968 still fits in 


\section{Dahlia Kashmiry, PhD}

the twenty first century. The American society is still divided into two Americas. One can notice that Bruce Norris also writes a two- Act play to divide the racial history in America into two eras. The first Act is set in 1959 and the second on in 2009 to highlight the idea that racism in the two eras does exist but it is practiced differently. In his play, Norris explains that there is no end even if time elapsed. The ugly face of the past throws its shadows in the present. The end of Jim Crow in 1970s doesn't mean the end of racism. On the contrary, African Americans find it more difficult nowadays to prove that they are being discriminated against because they lack the claim of systemic racism. The new racial practices are hard to detect. African Americans experience discrimination in the housing when they receive differential information about the availability of housing units. Some Blacks don't even know they are discriminated against until they compare the information they receive with their white counterparts. Considering labor market, African Americans are still underrepresented. There is always the invisible racial employer who refuses African Americans because s/he claims that they are not skilled workers. Sometimes the Whites claim that segregation is by choice. They justify school segregation, for example, by saying that parents should send their kids to the school they want. Concerning post- racial language, the Whites don't use direct racist language. The idea of using indirect racial language is highlighted in Norris's play. All his racial characters try to use indirect racial language to look nonracist. In Act two, Lindsey says "Half of my friends are black". She tries to appear non-racist by using the language as a tool to achieve this purpose. Actually Lindsey is a racist character because throughout the play she tries to renew the house in Clybourne Park without caring about the culture or history of the African Americans.

To conclude, Bruce Norris desires to draw the attention that racial practices are still produced, and the American society needs to understand that these practices work differently. So, the Americans have to do efforts to change these practices. It is not enough to have a black face in the White House like Barack Obama to prove the end of racism, but the African Americans' lives have to be improved economically, educationally, and socially. 


\section{From Shakespeare to Modern Ages}

\section{CONCLUSION}

Now, it is 2019 and the same question should be asked again: Has America entered the post racial era? Do American people still have two Americas, one for the white people and the other for the black people. After analyzing Clybourne Park, one can say that America has not entered the post racial era and there are still two Americas.

Using a unique and creative idea of the time span between the two Acts, Bruce Norris skillfully clarifies that racism still matters in the U.S although there is fifty years between the first and the second Act. Both Norris and Wilson show that racism still exists in the twenty first century.

Both white and black characters in Clybourne Park argue for their neighborhood to remain as it is-predominantly white or predominantly black. In the first Act Karl, the racist person wants to keep the neighborhood predominantly white. He speaks explicitly about race and tries to convince Russ and Bev not to sell their house to the Youngers. In the second Act, the situation changes, two white characters, Lindsey and Steve, want to move to a predominantly neighborhood and change the look and feel of the house. In the second act, the characters are hesitant to even bring up race when discussing their neighborhood, although it is a key factor in why Lena and Kevin feel uncomfortable with Lindsey and Steve's proposed renovations.

The play demonstrates how, although the language around race and racism has changed, little progress has been made towards being able to discuss race productively in America. The play doesn't present racism as an unresolved issue, rather it suggests that there are some moments in the play when racism disappear and all the characters can live together without having to remember the color of their skin. These moments appear when communication is done effectively. Not only can inside jokes and happy memories help unite couples and help families engage into small talk with one other, but communication is essential to resolving conflict and healing wounds.

The play is full of interrupted dialogues and miscommunications between characters. The second Act is a continually interrupted meeting. The couples fail to work through a twenty-page document. 


\section{Dahlia Kashmiry, PhD}

At these moments of failure everyone begins to attack the other and racism comes up to the surface. Francine in the first Act is always interrupted by Karl and Jim giving her no chance to state her opinions. Lena, in the second Act, is always trying to speak but she is continually interrupted by the others. The play's repeated breakdown of communication leads to frustration and even threats of violence. When two people are not communicating, it means that even in the best-case scenario, neither of them gets what they want, and in the worst case scenario, each person comes away thinking the other is a racist.

At the end of Clybourne Park, there is no clear message that the play offers. Rather, the Americans can think about their current situation considering racism and infer that nothing changes in the society. Considering the three plays, one can comfortably say that race and racism are still deeply woven in the American society.

\section{WORKS CITED}

\section{Primary Resources}

Norris, Bruce. Clybourne Park. New York: Farrar, Straus and Giroux, 2011. Print.

\section{Secondary Resources}

Bennett,Larry. "Gentrification". encyclopedia.chicagohistory.org, 2004.Web.14 July.2017.

Bonilla-Silva, Eduardo. Racism Without Racists: Color-blind Racism and the Persistence of Racial Inequality in Contemporary America. Maryland: Rowman\& Littlefield Publishers, Inc.2010.Print.

Brantley, Ben. "Good Defenses Make Good Neighbors". nytimes.com. February 21,2010. Web. Retrieved 5 January, 2018.

---. "Slashing the Tires on the Welcome Wagon.". nytimes.com,19 April 2012. Web. Retrieved 3 May.2017

---."Voices Warped by the Business Blues". nytimes.com, 30 April, 2005.Web. Retrieved 3 May.2017.

Brown, Alexander." Theater Review: Clybourne Park, Northern Stage". www.sevendaysvt.com, 5 November, 2014.Web. Retrieved 1 January, 2018.

Bureau of Justice. Prisoners of 2008. www.bjs.gov, December 2009.Web. Retrieved 4 July, 2017.

Dobbs,Lou. "Dobbs calls on listeners to rise above "partisan and racial element that dominates politics". www.mediamatters.org, 12 November.2009.Weh 


\section{From Shakespeare to Modern Ages}

13 March. 2017.

Kinder, D . R ,Lynn M .Sanders. Divided by Color. Chicago:The University of Chicago Press, 1996. Print.

Kinder, D. R., David O. Sears . "Prejudice and politics: Symbolic racism versus racial threats to the good life". Journal of Personality and Social Psychology. Vol.40, no. 3 (1981).Print.

King, Martin Luther."The Other America: A Speech by Martin Luther King". www.thekingcenter.org.Web. Retrieved. 13 April, 2018.

Kivel,Paul. Uprooting Racism. Canada: New Society Publishers.2011.print.

Manning, Christopher. "African Americans." www.encyclopedia.chicagohistory.org.Web. Retrieved.3 September, 2017.

Matthews, Chris." MSNBC's Matthews On Obama: "I Forgot He Was Black Tonight".www.youtube.com., 27January.2010.Web. Retrieved.March 13, 2017.

Meertens, Rowel W. Pettigrew. Thomas, F. "Is Subtle Prejudice Really Prejudice?" Public Opinion Quarterly. Vol.61 no. 54, (1997).Web. Retrieved, 21 January, 2018.

$<$ https://doi.org/10.1086/297786>.

Merrit, Pamela. "Post Racial America? Dream On". www.theguardian.com, 1 August 2009. Web. Retrieved, 13 March,2017.

Nolan, Ernest I. "The Racial Politics of Real Estate: Bruce Norris's Clybourne Park". International Journal of Humanities and Social Science, Vol. 3 no. 5(2013).print.

Noor. Poppy. "I feel guilty for gentrifying my neighbourhood. What should I do?". theguardian.com, 10 January, 2018.Web. Accessed, 14 January, 2018

Norris, Bruce. Interview by Beatrice Basso, Introduced by Dan Rubin. "Why does the 'Clybourne Park' playwright put such a premium on the freedom to provoke?". thefreelibrary.com, 1 Oct. 2011. Web. Retrieved, 11 Mar. 2018

Nyden,Philip. Emily Edlynn. Julie Davis. " The Differential Impact of Gentrification of Communities in Chicago". Loyola University Chicago Center for Urban Research and Learning. January 2006.issuelab.org. Web. 11 Mar.2018.

Obama, Barack. "President Obama: 'Post-Racial America After My Election' Unrealistic". An Interview by Lester Holt. youtube.com, 14 January, 2017. Web. <https://www.youtube.com/watch?v=U-ejkdjftw>. Retrieved,4 April, 2018.

Osborne, Jeremy William. "Clybourne Park". Thecolumnonline.com. 14 October, 2013. Web. Retrieved, 14 January, 2018. 


\section{Dahlia Kashmiry, PhD}

"The 'Post-Racial' Conversation, One Year In.". Talk of the Nation. Narr. Rebecca Roberts. NPR. National Public Radio, 18 January 2010. www.npr.org. Web. Retrieved, 20 March, 201

Rubin, Dan. "What is Gentrification".Words on Plays 20 January, 2011.actsf.org. Web. Retrieved, 3 May 2017.

The Lou Dobbs Show. Narr. Lou Dobbs. United Stations Radio Networks. 12 Nov. 2009. Mediamatters.org. Retrieved, Web. 5 May 2017.

The Reality of Hope. Perf. Lester Holt. NBC News. Television 14 Jan. 2017. Nbcnews.com. Web. Retrieved 7 May 2017.

State of the Uinon. Perf. Chris Mattews. MDNBC News. Television. 27 Jan. 2010. voices.washingtonpost. Web. Retrieved 5 May 2017.

"White Only: Jim Crow in America". National Museum of American History. americanhistory.si.edu.. Web. Retrieved, 3 May, 2017.

Zukin, Sharon, "Gentrification: Culture and Capital in the Urban Core". Annual Review of Sociology, Vol. 13,(1987). www.jstor.org. Web. Retrieved, 3 Augus ,2017. 